\title{
Padjadjaran Journal of InternationalRelations(PADIIR)
}

e-ISSN: 2684-8082 Vol. 3 No. 1, Januari 2021 (73-88) doi: 10.24198/padjir.v3i1.29391

\section{Corporate Diplomacy: Peran SM Entertainment melalui New Culture Technology dalam Diplomasi Publik Korea Selatan}

\author{
Maharani Putri \\ Program Studi Ilmu Hubungan InternasionalFISIP Universitas Andalas, Indonesia ; \\ maharaniputri2910@gmail.com \\ Sofia Trisni, S.IP, MA (IntRel) \\ Program Studi Ilmu Hubungan Interna sionalFISIP Universitas Andalas, Indonesia ; \\ sofi_hi01@yahoo.com \\ | submit: 08-09-2020 | accept: 25-01-2021 | publish: 31-01-2021
}

\section{Keywords \\ SM Entertainment, South Korea, Public Diplomacy, Corporate Diplomacy, New Culture Technology, Korean wave}

Kata Kunci

SM Entertainment, Korea Selatan, Diplomasi Publik, Corporate Diplomacy, New Culture Technology, Korean wave

\begin{abstract}
Public diplomacy is the primary key to soft power, often used by the governments of many countries, including South Korea, to achieve their national interest using culture and private actor power. As one of the private actors, Star Museum (SM) Entertainment made a positive contribution to South Korean culture's rapid absorption globally through the Korean wave. This research analyze the corporate strategy of SM Entertainment, knowns as New Culture Technology (NCT), and it's relations with the public diplomacy carried out by the South Korean Government, using the concept of corporate diplomacy. This research is a qualitative research done through literature study by analyzing SM Entertainment's activities and examining whether those activities match corporate diplomacy. This research found that SM Entertainment's role in South Korean public diplomacy was applying New Culture Technology (NCT) strategy in cultural diplomacy activities, foreign investment, branding (place/nation/destination), brand and products development, and the implementation of Corporate Social Responsibility (CSR).
\end{abstract}

\footnotetext{
ABSTRAK

Diplomasi publik merupakan kunciutama dari soft power yang sering digunakan oleh pemerintah berbagai negara di dunia, termasuk Korea Selatan, untuk mencapai kepentingan nasionalnya dengan memanfaatkan kekuatan budaya dan aktor swasta. Sebagai salah satu aktor swasta, Star Museum (SM) Entertainment memberikan kontribusi positif terhadap diserapnya budaya Korea Selatan dengan cepat secara global melalui Korean wave. Penelitian ini menganalisis strategi perusahaan SM Entertainment yang dikenal dengan New Culture Technology (NCT) dan hubungannya dengan diplomasi publik yang dilaksanakan oleh Pemerintah Korea Selatan dengan menggunakan konsep corporate diplomacy. Penelitian ini merupakan penelitian kua litatif melalui studipustaka dengan menganalisis aktivitas-aktivitas yang dilakukan oleh SM Entertainment dan menguji apakah aktivitas tersebut sesuai dengan konsep corporate diplomacy. Penelitian ini menemukan bahwa SM Entertainment berperan dalam diplomasi publik Korea Selatan dengan mengaplikasikan strategi New Culture Technology $(N C T)$ dalam aktivitas diplomasi kebudayaan, penanaman modal asing, kegiatan branding (place/nation/destination), pengembangan brand dan produk, serta pelaksanaan Corporate Social Responsibility (CSR).
} 


\section{PENDAHULUAN}

Kajian mengenai diplomasi publik tidak terlepas dari peran negara melalui aktivitasaktivitas diplomatiknya. Meski demikian, saat ini berbagai aktor non-negara juga dapat berperan langsung dalam diplomasi publik. Penelitian ini berupayamenjelaskan bagaimana aktor non-negara - dalam hal ini perusahaan swasta yaitu Star Museum Entertainment, atau lebih dikenal dengan SM Entertainment, melalui strategi perusahaannya dapat memberikan kontribusi dalam diplomasi publik Korea Selatan.

Diplomasi publik merupakan terminologi yang selalu dikaitkan dengan soft power, yaitu kemampuan membuat pihaklain menginginkan hal yang sama dengan cara-cara yang cenderung persuasif ketimbang melakukan pemaksaan (Nye, 2008). Diplomasi publik sebagai salah satu kunci utama dari soft power telah diakui dalam praktek diplomatik jauh sebelum berkembangnya perdebatan kontemporer mengenai diplomasi publik tersebut (Melissen, 2006). Dalam politik internasional, sumber daya yang dimiliki suatu negara seperti misalnya kebudayaan, muncul sebagai soft power dan pemerintah menggunakan diplomasi publik sebagai instrumen untuk memobilisasi sumber daya tersebut dalam berkomunikasi dan mengambil hati publik di negara lain(Nye, 2008).

Seiring perkembangan jaman, diplomasi publik juga semakin berkembang dengan cakupan yang luas baik dari segi isu maupun aktor yang menjalankan diplomasi tersebut. Saat ini aktor diplomasi publik semakin beragam yang mana selain negara, diplomasi publik juga dapat melibatkan organisasi, badan usaha, pebisnis, kelompok kepentingan, sampai individu, terutama dengan kecenderungan publik post-modern yang skeptis dan seringkali menaruh kesalahpahaman terhadap aktor negara (Nye, 2008) Berkurangnya dominansi negara inilah yang menyebabkan munculnya istilah multi-track diplomacy. John W. McDonald membagi diplomasi ke dalam sembilan tingkatan sesuai penempatan aktoraktor non-negara. Menurut McDonald, diplomasi tingkat ketiga membahas mengenai aktivitas bisnis yang dianggap berpotensi untuk mempengaruhi kesan atau pandangan negara lain terhadap negara tersebut (McDonald, 2012). Sejalan dengan pandangan McDonald, ahli-ahli seperti Candace L. White, Endric Ordeix Rigo, dan Joao Duarte semakin memberikan dukungan pada adanya potensi aktor non-negara khususnya perusahaan dalam diplomasi publik suatu negara. Rigo dan Duarte bahkan menegaskan bahwa perusahaanperusahaan saat ini memainkan peranan penting dalam diplomasi publik di dunia hubungan internasional (Ordeix-Rigo \& Duarte, 2009)

Fenomena demikian juga dapat dilihat pada dinamika diplomasi publik Korea Selatan. Pemerintah Korea Selatan saat ini sering kali memanfaatkan kebudayaan yang dimiliki negaranya sebagai instrumen diplomasi publik demi menimbulkan citra positif negara bagi masyarakat internasional, dapat dilihat dari luasnya penyebaran produk-produk kebudayaan Korea Selatan yang diterima dengan baik oleh masyarakat global. Gelombang penyebaran budaya Korea Selatan yang dikenal dengan Hallyu atau Korean wave adalah salah satu instrumen yang diadaptasi oleh Pemerintah Korea Selatan dalam agenda diplomasi publik negaranya dan digunakan sebagai soft power (Lee, Geun, 2009). Semenjak pemerintahan Presiden Kim Dae Jung (1993-1998), pemerintah Korea Selatan memberikan dukungan penuh untukgelombang yang membawa misi diplomasi publikini (Putri et al., 2019). Dengan adanya peran pemerintah sebagai pendukung, aktor-aktor swasta hadir sebagai pihak yang menjadi eksekutor dalam pelaksanaan diplomasi publik, salah satunya yang dibahas dalam artikel ini adalah SM Entertainment.

Berangkat dari adanyaperkembangan dalam konsep diplomasi publik yang mengindikasikan bahwa aktor-aktor lain termasuk perusahaan juga dapat memberikan kontribusi dalam pelaksanaan diplomasi tersebut, maka fenomena yang dimiliki Korea Selatan yang melibatkan SM Entertainment dalam pelaksanaan diplomasi publik negaranya 
sangat menarik untuk diteliti. Penelitian ini diharapkan dapat menjadi salah satu rujukan dalam literatur Ilmu Hubungan Internasional terkait diplomasi publik, yang mana menggambarkan bagaimana SM Entertainment dengan statusnya sebagai aktor non-negara justru juga dapat berkontribusi untuk menumbuhkan citra baik negaranya secara internasional.

\section{KERANGKA KONSEPTUAL}

Public Dipomacy atau diplomasi publik secara sederhana merupakan proses di mana aktoraktor internasional berusaha untuk mencapai tujuan dari kebijakan luar negeri mereka dengan cara terlibat dengan publik asing (Cull, 2008). Artikel ini menggunakan salah satu dari berbagai jenis public diplomacy sebagai konsep yaitu corporate diplomacy.

Corporate diplomacy merupakan konsep yang mengacu kepada peranan korporat/perusahaan yang di dalam diplomasi publik. Negara tetap diakui sebagai aktor utama dan pusat dari diplomasi publik, namun ada dukungan yang semakin berkembang terhadap anggapan bahwa aktor non-negara termasuk perusahaan internasional dapat memainkan peran dan memberikan kontribusi kepada outcome diplomasi publik negara tersebut (White, 2015). Para sarjana dari Pusat Diplomasi Publik dari University of Southem California mendefinisikan diplomasi publik yang berkaitan dengan keterlibatan aktor nonnegara ini sebagai usaha negara melalui institusi resmi maupun privat untuk berkomunikasi dengan publik di luar negara, yang mana tidak hanya berkenaan dengan program-program pemerintah, namun juga mencakup pertukaran masyarakat, siaran media swasta, dan komunikasi perusahaan demi mempromosikan kepentingan negara melalui usaha-usaha mempengaruhi masyarakat luar(White, 2015).

Meski seringkali tujuan pendirian perusahaan swasta adalah profit, hal ini tidak mutlak mendefinisikan bahwa perusahaan tidak dapat memiliki peran sama sekali dalam diplomasi publik. Demi lebih menjelaskan mengenai peranan perusahaan dalam diplomasi publik, White memberikan perbandingan dalam perbedaan duakonsep yaitu business diplomacy dan corporate diplomacy. Keduanya adalah diplomasi yang sama-sama dilakukan oleh aktor non-negara yaitu perusahaan, namun memiliki tujuan berbeda, di mana business diplomacy memiliki tujuan tunggal yaitu mencapai target bisnis, sedangkan corporate diplomacy di sisi lain dapat memberikan keuntungan baik itu kepada perusahaan maupun kepada negara asalnya (White, 2015). Hal ini sejalan dengan argumen dari Ordeix dan Duarte yang menegaskan bahwa corporate diplomacy merupakan sebuah kemampuan yang dimiliki dan dikembangkan perusahaan transnasional besar untuk diimplementasikan dalam program independen mereka, yang pada akhirnya dapat mencapai tujuan diplomasi publik yang sejalan dengan yang diusahakan negara (Ordeix-Rigo \& Duarte, 2009).

Keterlibatan suatu perusahaan dalam diplomasi publik yang mana mencerminkan citra dan reputasi dari negara asal perusahaan tersebut dapat disengaja maupun tanpa disengaja. White menjabarkan kedua aspek (kesengajaan maupun ketidaksengajaan) tersebut dengan memunculkan beberapa contoh. Contoh pertama adalah organisasiorganisasi seperti Ford atau Rockefeller Foundations yang memang sengaja didirikan untuk tujuan pertukaran budaya. Sedangkan contoh lain misalnya aktivitas CSR yang dilakukan Chevron dengan menyediakan layanan kesehatan bagi masyarakat di mana perusahaan itu berdiri, menimbulkan dampak positif terhadap citra Amerika Serikat. Kesuksesan CSR oleh Chevron dalam membangun citra positif negara tersebut diidentifikasikan sebagai kontribusi terhadap proses diplomatik yang tidak direncanakan sebelumnya. Dengan contoh-contoh demikian, masuk akal apabila dikatakan bahwa image suatu negara juga menjadi tanggung jawab dari perusahaan-perusahaannya. 
Corporate diplomacy atau keterlibatan sektor perusahaan dalam diplomasi publik dapat terjadi baik ketika perusahaan itu bertindak secara independen maupun bekerja sama dengan pemerintah negaranya (White, 2015). Aktivitas-aktivitas yang dilakukan perusahaan adalah demi membangun keuntungan bagi perusahaan itu sendiri, sekaligus juga menguntungkan bagi negara di mana perusahaan tersebut berdiri yang mana memenuhi peranannya dalam diplomasi publik. White menambahkan ada beberapa aktivitas bisnis yang kemudian dapat dikategorikan sebagai kontribusi perusahaan dalam proses diplomasi publik :

1. Foreign Policy/Political Communication: Kebijakan luar negeri yang diputuskan oleh negara dan komunikasi politik sebagai bentuk diplomasi publik oleh state actor bertujuan demi tercapainya kepentingan nasional.

2. Cultural Diplomacy : Salah satu sub-set dari diplomasi publik yang dalam hal ini tidak hanya berupa pertukaran budaya yang disponsori oleh negara melainkan juga dapat berupa aktivitas pertukaran kebudayaan oleh aktor-aktor non-negara.

3. Foreign Investment / Economic Policy / Foreign Aid : Investasi asing, kebijakan ekonomi, maupun bantuan luar negeri yang dapat melibatkan baik negara maupun non-negara.

4. Branding: Place / Nation/Destination: Nation Branding beserta komponenkomponennya (misalnya promosi tempattempat atau destinasi wisata). Definisi nation branding itu sendiri salah satunya adalah proses membangun dan mengelola identitas dan citra suatu negarasecara jelas untuk menarik dan memenuhi kebutuhan pemangku kepentingan baik internal maupun external, pengunjung, dan investor (Odia \& Isibor, 2014:206). selain inisiasi oleh negara, aktivitas branding biasanya juga dilakukan oleh aktor nonstate yaitu perusahaan swasta seperti pengembangan resor dan lain-lain.
5. Brands/Products/Export : Komoditi yang dihasilkan suatu perusahaan, brand, dan produk-produknya yang di ekspor ke luar negeri, yang berdampak terhadap reputasi nasional negara.

6. Corporate Social Responsibility (CSR) : Merupakan salah satu bentuk soft diplomacy berupa berbagai kegiatan sosial yang dilakukan perusahaan sebagai bentuk tanggung jawab sosial perusahaan bersangkutan, yang apabila berhasil dilakukan, maka akan sangat besar kontribusinya terhadap image negara.

Konsep Corporate Diplomacy ini akan digunakan untuk menjelaskan kontribusi perusahaan yang dapat diberikan SM Entertainment terhadap diplomasi publik Korea Selatan melalui New Culture Technology (NCT) terutama dengan potensi yang dimiliki perusahaan ini untuk berperan dalam diplomasi publik negaranya.

\section{METODE RISET}

Penelitian ini merupakan jenis penelitian deksriptif dengan pendekatan penelitian kualitatif. Data yang digunakan dalam penelitian kali ini didapatkan dari hasil studi pustaka dan penelitian berbasis dokumentasi. Penelitian perpustakaan dilakukan dengan cara mencari dan mengamati literatur yang sejalan dengan permasalahan yang diangkat pada penelitian. Beberapa kata kunci utama yang digunakan dalam pencarian literatur adalah Public Diplomacy, Corporate Diplomacy, Korean Wave, SM Entertainment, dan Culture Technology. Literatur berupa jurnal, buku, makalah, skripsi, disertasi, dan publikasi lainnya yang sekiranya dapat membantu untuk dijadikan pedoman dalam proses penelitian.

\section{HASIL DAN PEMBAHASAN}

SM Entertainment dan Strategi New Culture Technology (NCT)

SM Entertainment merupakan perusahaan swasta berupa agensi hiburan berbasis kebudayaan Korea Selatan yang secara resmi didirikan pada tahun 1995 oleh Lee Soo Man 
sebagai founder dan head producer (SM Entertainment, n.d.-a). SM Entertainment secara umum beroperasi sebagai label rekaman, perusahaan produksi musik dan konser, manajemen acara dan rumah penerbitan musik. Semenjak awal berdirinya perusahaan ini sampai sekarang, SM Entertainment menjadi aktor di luar lembaga pemerintahan yang terdepan dan diakui oleh Pemerintah Korea Selatan dalam memimpin gelombang penyebaran budaya Korea atau Hallyu. Sebagai bukti pengakuan dari Pemerintah Korea Selatan, SM Entertainment menjadi salah satu perusahaan hiburan yang labelnya disebutkan dalam laman web Kedutaan Besar Republik Korea sebagai Agensi yang sukses menyebarkan demam Korea (Kedutaan Besar Republik Korea untuk Republik Indonesia, n.d.).

Pengakuan dan dukungan dari pemerintah terhadap kegiatan SM Entertainment bukan tanpa alasan, melainkan sebagai buah dari prestasi Lee Sooman selaku founder dari SM Entertainment yang mencetuskan konsep yang dapat dikatakan bertanggung jawab terhadap meledaknya hype budaya K-Pop dan budaya Korea Selatan lainnya di pasar internasional. Strategi Culture Technology milik Lee Sooman yang saat ini dikenal dengan New Culture Technology (NCT) adalah titik awal dari digemarinya kebudayaan Korea Selatan melalui gelombang penyebaran budaya kedua (Shin Hallyu). Lee Sooman melakukan proses awal industrialisasi K-Pop dengan melakukan riset kepada selera gadis-gadis remaja sebagai target konsumen potensial mengenai seperti apa kriteria idola yang ideal bagi mereka (Shim, 2006). Hasil riset tersebut kemudian ditindaklanjuti oleh Lee Sooman dengan melakukan perekrutan terhadap talenta-talenta calon idola yang sesuai dengan kriteria para calon penggemar. Proses dari mulai pencarian bakat, perekrutan, pelatihan, sampai pengorbitan bintang-bintang dari SM Entertainment ini telah direncanakan dalam tahap 'produksi' pada New Culture Technology (Lee, 2014). Proses ini merupakan proses awal yang membuahkan hasil terbukti dengan maraknya penggemar K-Pop seperti yang bisa dilihat saat ini.

Pada tahun 2016, Lee Sooman memperkenalkan pembaharuan dari Culture Technology yang telah dijalankan oleh SM Entertainment selama 20 tahun yang mana inovasi ini dinamakan New Culture Technology (NCT) (SMTOWN, 2016). Selain melanjutkan strategi yang telah lama digunakan pada Culture Technology (CT), New Culture Technology (NCT) membawa programprogram baru yang semakin menyempurnakan strategi perusahaan SM Entertainment. Apabila diuraikan maka secara garis besar kerangka kerja New Culture Technology (NCT) adalah sebagai berikut :

A. Proses Produksi

Proses ini berupa tahapan-tahapan yang dilakukan SM Entertainment dari mulai mencari talenta sampai kepada memproduksi artis-artis yang nantinya akan menjadi perwakilan dalam penyebaran budaya. Proses produksi terdiri dari 3 tahapan yakninya:

a. Casting $\rightarrow$ Dalam mencari bakat-bakat yang akan direkrut, SM Entertainment menggunakan berbagai metode seperti street casting (merekrut anak-anak muda secara acak di jalanan Korea Selatan), Saturday audition (audisi terbuka di akhir pekan), dan global casting.

b. Training $\rightarrow$ Melatih para calon artis dengan pengembangan bakat melalui SM's Artist Development System.

c. Producing $\rightarrow$ Memproduksi kontenkonten kreatif mulai dari musik, kostum, sampai video. Dalam proses produksi konten ini, SM Entertainment bekerja sama dengan produser baik dalam maupun luar negeri.

B. Pemasaran (Marketing/Management) : SM Entertainment memiliki karakteristik bisnis luar negeri yang diversifikatif atau sangat beragam, hal ini dikarenakan SM Entertainment menafsirkan bisnis K-Pop 
sebagai bisnis Kebudayaan Korea Selatan

(Lee, 2014). SM Entertainment mewujudkan diversifikasi tersebut ke dalam bisnis $360^{\circ}$ yang mencakup :

a. Bisnis Pertunjukan Langsung : SM Entertainment memperluas kepopuleran produk budaya Korea Selatan yang dihasilkan perusahaannya melalui pertunjukan-pertunjukan seperti konser musik ke berbagai negara.

b. Produksi Film \& Drama dibintangi artisartis SM Entertainment yang dipasarkan secara global.

c. Memasuki program siaran di stasiun televisi lokal negara-negara target pemasaran seperti ABC Broadcasting Amerika Serikat atau berbagai macam talkshow negara tersebut.

d. Bisnis Ekspor Hak Cipta : SM Entertainment menjalin kontrak dengan perusahaan-perusahaan luar negeri yang ingin menyiarkan atau menggunakan produk-produk kebudayaan yang telah dipaten oleh SM Entertainment.

Selain itu, khususnya dalam promosi dan pemasaran artis-artisnya sebagai upaya penetrasi memasuki pasar global, SM Entertainment memiliki beberapa strategi utama yaitu :

a. Lokalisasi : Artis-artis yang direkrut oleh

SM Entertainment tidak terbatas hanya dari kalangan masyarakat asli Korea Selatan saja, melainkan sudah dari berbagai negara. Dalam kasus grup idola misalnya, akan terlihat beberapa dari anggota grup tersebut merupakan nonKorea seperti dari China, Jepang, Amerika Serikat, dan sebagainya sehingga pada umumnya grup tersebut akan lebih diterima oleh negara-negara asalnya.

b. Diversifikasi Saluran Distribusi : Selain melakukan promosi di stasiun televisi nasional Korea Selatan, SM Entertainment juga gencar menggunakan layanan jejaring sosial seperti Youtube, Facebook, Twitter, Kakaotalk, Line, atau Weibo sebagai platform distribusi produk mereka. c. Pemasaran omnidirectional : Kegiatan selebriti SM Entertainment tidak hanya sebatas melakukan pertunjukan, tapi juga membuat dirinya dikenal di pasar luar salah satunya dengan menjadi model dari merk-merk (brand) luar negeri seperti Lacoste, Pepsi Cola, dan lainnya.

d. Strategi Diferensiasi Negara : SM Entertainment menyadari perbedaan yang dimiliki negara satu sama lain dalam hal konsumsi produk-produk budaya, sehingga setiap produk akan menyesuaikan dengan selera pasar yang ditargetkan.

New Culture Technology (NCT) inilah yang dimunculkan pada artikel ini sebagai strategi yang digunakan oleh SM Entertainment dalam aktivitas-aktivitas perusahaannya, yang mana membuat SM Entertainment menjadi salah satu perusahaan yang berperan dalam diplomasi publik Korea Selatan sesuai konsep corporate diplomacy.

Pemerintah Korea Selatan, Hallyu, dan SM Entertainment

Hallyu (Korean wave) merupakan istilah yang dipakai untuk mewakili fenomena populernya budaya Korea Selatan dan semakin meningkatnya popularitas tersebut saat ini baik di Asia dan daerah lain di dunia (Kedutaan Besar Republik Korea untuk Republik Indonesia, n.d.). Istilah Hallyu pertama kali dipopulerkan oleh para jurnalis di Beijing sebagai reaksi terhadap maraknya peminat budaya K-Pop dalam waktu singkat, yang kemudian juga menyebar tidak hanya di Tiongkok, namun juga ke dalam negara-negara Asia seperti Hongkong, Taiwan, dan Vietnam (Huat \& Iwabuchi, 2008). Istilah Hallyu kini digunakan untuk menyebut apapun yang berkaitan dengan dengan merebaknya budaya populer Korea Selatan ke pelbagai negara di seluruh dunia yang mana melalui musik, film, drama, gaya hidup, sampai sepakbola, budaya populer ini mendominasi selama bertahuntahun (Huat \& Iwabuchi, 2008). 
Merujuk kepada sejarah Korea Selatan, kemunculan Hallyu dapat dikatakan tidak terlepas dari berbagai krisis yang dialami Korea Selatan pada tahun-tahun sebelum Hallyu. Sama halnya dengan negara-negara Asia Timur lainnya seperti Jepang atau China, Korea Selatan juga merupakan salah satu negara yang mampu bangkit dari keterpurukan ekonomi pada masa krisis. Meski demikian, penyebab dari kebangkitan ini tidak bisa diklaim hanya melalui faktor-faktor ekonomi saja, melainkan harus mengikutsertakan aspek budaya (Hennida et al., 2017). Korean wave sebagai gelombang besar budaya Korea Selatan telah diagendakan oleh pemerintah untuk mempengaruhi pandangan publik negara luar terhadap produk-produk Korea Selatan pasca krisis finansial 1998 yang menyebabkan turunnya pendapatan domestik bruto negara ini secara drastis yaitu sebesar 7\% (The Economist, 2010). Kebijakan kultural dalam mendukung Korean Wave disadari oleh pemerintah Korea Selatan selain dapat digunakan sebagai motor penghasilan untuk melunasi hutang, secara bersamaan juga dapat menciptakan citra yang baik bagi negara sehingga pemerintah memberikan perhatian lebih pada sektor ini (Trisni, 2019).

Kesadaran tentang pentingnya nilai-nilai budaya nasional dan potensinya untuk dimanfaatkan dalam mencari kesejahteraan sudah mulai ada semenjak pemerintahan Presiden Kim Young Sam (1993-1998). Pada pembukaan Seventh Conference for The Promotion of New Economy yang diadakan di Seoul tahun 1994, Presiden Kim Young Sam menyatakan bahwa Korea Selatan siap bersaing dalam bidang budaya dan Ekonomi baru secara global (Hilda, 2018). Pernyataan tersebut didukung dengan pendapat Presiden Kim yang menyatakan bahwa saat ini adalah era di mana budaya memegang kendali atas nasib bangsabangsa. Meskipun sebelumnya eksistensi budaya Korea Selatan sempat bahkan tidak diakui oleh para peneliti sebagai komoditi ekspor yang memadai, beberapa tahun belakangan berbagai produk kebudayaan Korea Selatan telah merajai pasar dunia (Shim, 2006).

Ketika pemerintah menjadi pihak yang mendukung hallyu, maka SM Entertainment merupakan salah satu perusahaan yang menerima dukungan oleh pemerintah Korea Selatan dalam menyebarkan gelombang kebudayaan ke berbagai belahan dunia. SM Entertainment memang menjadi salah satu agensi yang menerima saluran dana investasi dari pemerintah Korea Selatan sebagai stimulator dalam pengembangan industri budaya. Pemerintah Korea Selatan yang menyadari adanya potensi dari industri kreatif hallyu mulai mengambil peran sebagai dalam menyediakan lahan investasi bagi para chaebol (konglomerat) untuk kemudian dialokasikan salah satunya kepada SM Entertainment (Trisni, 2019). Salah satu contoh spesifik dari penyaluran dana investasi chaebol oleh Pemerintah Korea Selatan kepada SM Entertainment terlihat mulai dari akhir 1980-an hingga awal 1990-an (Jung \& Shim, 2014). Distribusi dana ini mendukung modernisasi sistem produksi musik di Korea Selatan.

Didukung dengan bantuan penyaluran dana oleh pemerintah, Culture Technology milik SM Entertainment-lah yang membuat perusahaan ini dapat dikatakan sukses sebagai eksekutor Hallyu. Berbekal konsep Culture Technology, SM Entertainment sukses dalam industrialisasi proses pengorbitan bintang-bintang ternama yang memimpin "Shin Hallyu" atau Korean wave gelombang kedua (semenjak awal tahun 2000-an). Culture Technology dipraktekkan Lee Soo Man dari awal mula pencarian talentatalenta yang akan direkrut dengan berbekal hasil research untuk mengetahui selera remaja, kemudian menggelar berbagai audisi untuk dilatih dalam periode tertentu dan didebutkan.

Contoh produk terbaik yang dapat mewakili kesuksesan SM Entertainment pada masa itu adalah boyband H.O.T yang debut pada tahun 1996. H.O.T mengalami ledakan dalam hal popularitas dengan mencetak lebih dari 10 juta CD dan rekor penjualan di Korea selama eksistensinya dari tahun 1996-2001 (Jung \& 
Shim, 2014). Berkat kesuksesan H.O.T sebagai boyband pertama produksi SM Entertainment, media Korea Selatan mulai mengenal metode perencanaan dan manajemen dalam pencarian bakat. Lee Soo Man mendapat berbagai penghargaan dan selalu dikreditkan pada setiap pengembangan Culture Technology yang mana pendekatan tersebut saat ini juga digunakan oleh agensi-agensi hiburan lain termasuk agensi terbesar kedua dan ketiga di Korea Selatan yaitu YG Entertainment dan JYPEntertainment (Chen, 2016).

\section{Implementasi New Culture Technology} SM Entertainment pada Diplomasi Publik Korea Selatan

Pada era yang sudah berkembang saat ini, diplomasi juga telah menunjukkan perkembangan yakni tidak hanya sebatas dengan melakukan kunjungan resmi dan aktivitas-aktivitas diplomatik yang dilakukan aktor negara seperti layaknya diplomasi tradisional. Diplomasi kebudayaan sebagai salah satu sub-set dari diplomasi publik merupakan salah satunya yang mampu memperlihatkan bukti nyata perkembangan tersebut. Melalui diplomasi kebudayaan, masyarakat secara global mampu menjalin hubungan yang baik melalui pertukaran budaya tanpa harus was-was dengan tindakan mengancam dari negara lain dan kemungkinan propaganda. Di samping berbagai keuntungan yang menyertai pelaksanaan diplomasi kebudayaan, salah satu yang paling menonjol adalah jenis diplomasi ini mampu membangun citra baik negara yang melakukannya di mata negara lain bahkan dunia (U.S. Department of State, 2005). Hal inilah, seperti yang telah disinggung pada bagian sebelumnya, yang menjadi pendorong bagi pemerintah Korea Selatan untuk mengakui potensi kebudayaan mereka dalam memperbaiki citra di samping menjadi motor kemajuan ekonomi, sehingga pemerintah Korea Selatan mulai mendukung gelombang penyebaran budaya atau hallyu.

SM Entertainment sebagai perusahaan swasta turut ambil bagian pada diplomasi kebudayaan Korea Selatan, ditunjukkan dengan keikutsertaan perusahaan ini dalam kegiatan diplomasi ke berbagai negara. Dalam perayaan 40 tahun hubungan diplomatis antara Korea Selatan dengan Indonesia, pemerintah Korea Selatan mendukung pagelaran konser K-Pop bertajuk "Music Bank in Jakarta" pada tahun 2013. Dua grup idola yang berasal dari SM Entertainment yaitu Super Junior dan SHINee diikutsertakan dalam pagelaran konser tersebut (Ramirez, 2013). Sebelum konser "Music Bank in Jakarta" tahun 2013 tersebut, SM Entertainment sebenarnya sudah beberapa kali menyelenggarakan konser bagi artis-artis mereka di Indonesia. Super Junior yang kala itu memiliki banyak penggemar di Indonesia semenjak rilisnya lagu "sorry sorry" mengadakan konser tunggal pada bulan April 2012 (Hazliansyah, 2012). Karena besamya antusiasme fans dan banyaknya permintaan, akhirnya promotor konser menambah jumlah hari pelaksanaan konser menjadi tiga hari. Selain Super Junior, pada tanggal 22 September 2012, SM Entertainment kembali menggelar konser musik di Indonesia yang kali ini memboyong seluruh grup idola asuhan agensi ini dalam konser yang bertajuk "SMTOWN Live World Tour III in Jakarta" (W Production, 2012). Melalui konser ini, SM Entertainment berhasil menarik 50.000 penonton dan mencetak rekor sebagai konser K-Pop terbesar dan termegah pertama yang diadakan di Indonesia. Kesuksesan kedua konser ini kemudian menjadi motivasi bagi artis-artis Korea Selatan lainnya untuk turut mengadakan pertunjukan di Indonesia, sehingga dapat dikatakan SM Entertainment telah menjadi pembuka jalan bagi kepopuleran masif budaya pop Korea di Indonesia saat ini.

Selain Indonesia, beberapa negara lain juga telah menjadi sasaran pelaksanaan diplomasi budaya oleh SM Entertainment. Beberapa di antaranya yaitu Korea Utara (2018), dan Malaysia (2019). Pada bulan Maret 2018, Pemerintah Korea Selatan mengumumkan bahwa KoreaSelatan akan mengirimkan musisi dari Korea Selatan untuk tampil di KoreaUtara. Kunjungan ini dimaksudkan sebagai kunjungan 
balasan setelah kelompok seni Korea Utara tampil membawakan orkestra pada Olimpiade Musim Dingin Pyongchang 2018 (Armenia, 2018). Pemerintah Korea Selatan mengirimkan total 160 artis yang di antaranya termasuk grup idola wanita asuhan SM Entertainment yaitu Red Velvet. Pada tahun 2019, salah satu grup asuhan SM Entertainment yaitu NCT Dream ikut serta sebagai perwakilan Korean Wave dalam rangkaian acara kenegaraan yang dihadiri langsung oleh Presiden Korea Selatan Moon Jae-in.

Beberapa contoh di atas adalah implementasi dari strategi yang terdapat dalam New Culture Technology milik SM Entertainment. Merujuk kepada kerangka kerja NCT, strategi yang tampak digunakan dalam diplomasi budaya adalah strategi "produksi dan industrialisasi K-Pop. Seperti disinggung sebelumnya, produksi dan industrialisasi produk kebudayaan pada NCT oleh SM Entertainment adalah terlebih dahulu melalui tiga tahapan; casting, training, producing. Ketiga tahapan tersebut menghasilkan produkproduk budaya, yang diwakili oleh selebriti dari SM Entertainment dan digemari secara global sehingga membuat perusahaan ini mampu berperan dalam diplomasi budaya dan menimbulkan citra baik untuk Korea Selatan dengan budayanya.

Contoh lain yang signifikan terkait keterlibatan SM Entertainment dalam diplomasi publik Korea Selatan melalui NCT dapat dilihat dalam kegiatan branding yang dilakukan oleh SM Entertainment. Kegiatan branding sesuai dengan konsep corporate diplomacy White merupakan salah satu komponen penting dalam diplomasi publik, sama halnya dengan diplomasi kebudayaan dan dapat dilakukan baik oleh negara maupun sektor privat (White, 2015). Bagi Korea Selatan sendiri, SM Entertainment merupakan aktor yang diakui dalam kegiatan branding. Pemerintah daerah Seoul Korea Selatan pernah mengikutsertakan artis-artis dari SM Entertainment yaitu TVXQ, Super Junior, dan Girls' Generation dalam rangkaian promosi kota Seoul pada tahun 2014. Melalui laman resmi Global Seoul, serial video komersial dengan tema "Infinitely Yours, Seoul" yang dibintangi oleh ketiga grup artis SM Entertainment tersebut dirilis pada tahun 2009. SM Entertainment juga mengeluarkan lagu dan video musik kolaborasi antara Super Junior dan Girl's Generation dengan tema yang sama berjudul "Seoul Song", dalam rangka promosi kota Seoul secara global di chanel youtube resmi perusahaan tersebut. Selain melalui youtube SM Entertainment, video komersial tersebut disiarkan secara global di berbagai stasiun televisi China, Jepang, Asia Tenggara dan Amerika. Selain strategi produksi dan industrialisasi, strategi NCT yang menonjol pada kegiatan branding ini adalah diversifikasi dalam saluran distribusi dan juga pemasaran. Dapat dilihat, SM Entertainment gencar mendistribusikan konten-konten promosi budaya, pariwisata dan keunggulan lain yang dimiliki negaranya melalui berbagai platform.

Sama halnya dengan kegiatan branding nation, place, destination, perusahaan SM Entertainment juga sangat sering dipercayai oleh pengusaha produk-produk kebudayaan Korea Selatan untuk menjadi ambassador bagi produk mereka. Berikut beberapa brand Korea Selatan yang mempercayakan produknya di bawah promosi oleh SM Entertainment:

1. Missha Cosmetic : BoA (2003-2006, 2012), TVXQ(2011, 2012,2013)

2. Nature Republic : Taeyeon Girls' Generation (2013), EXO (2013-2020), NCT 127 (2020)

3. Etude House : S.E.S (2000-2001), Go Ara (2006-2008), SHINee (2012), Sulli \& Krystal f(x) (2013-2014), Krystal f(x) (2015-2017), Red Velvet (2018 sampai sekarang)

4. Innisfree : Yoona Girls' Generation (2009 sampai sekarang)

5. The Saem : SHINee (2015), Red Velvet (2016)

Dipilihnya para artis SM Entertainment tersebut sebagai ambassador untuk promosi 
global berbagai produk Korea selatan pada umumnya adalah karena image baik yang mereka miliki. Perwakilan dari brand The Saem misalnya, mengungkapkan bahwa motivasi mereka memilih Red Velvet adalah karena energi positif dan image sehat dan segar yang ditampilkan Red Velvet sangat cocok dengan konsep eco global yang mereka usung untuk produk-produk The Saem (An0ya, 2016). Tidak hanya produk kosmetik, artis SM Entertainment juga amat sering menjadi model untuk produk-produk lain seperti brand fashion, makanan, dan masih banyak lagi. Strategi pemasaran omnidirectional yang dimiliki SM Entertainment dalam kerangka kerja NCT membuat kegiatan para selebriti di perusahaan ini tidak terbatas kepada pertunjukan saja melainkan juga membuat dirinya di pasar luar dengan tidak hanya menjadi model produk Korea Selatan tetapi juga produk-produk luar negeri seperti Lacoste, Gucci, Pepsi Cola, dan brand lainnya.

Menjadi ambassador untukberbagai produk tidak membatasi kegiatan branding oleh SM Entertainment. Selain menjadi agensi yang mengorbitkan bintang-bintang ternama, SM Entertainment sendiri merupakan sebuah brand mandiri yang juga memproduksi berbagai produk sendiri dibawah brand tersebut. Semenjak tahun 2017, SM Entertainment merilis identitas perusahaan yang baru (SM Entertainment, 2017). Corporate Identity (CI) yang baru di sini dimaksudkan untuk meresmikan pembaharuan terhadap sistem brand dan identitas di mana nantinya akan menunjukkan fleksibilitas SM Entertainment dalam menangani berbagai konten seperti entertainment, new media, dan lifestyle. Perubahan tersebut merupakan ide dari Lee Sooman yang juga mempersiapkan Artificial Intelegence (AI) atau kecerdasan buatan dalam pengembangan konten dan produk SM Entertainment di masa depan mengikuti pembaharuan CT ke NCT pada tahun 2016. Pembaharuan Corporate Identity SM Entertainment dimulai dengan perubahan pada identitas visual (logo) SM Entertainment sebagaimana dipresentasikan dalam video singkat yang diunggah di lama facebook SM Entertainment. Video tersebut diawali dengan cahaya yang merepresentasikan para artis dan konten SM Entertainment, kemudian cahaya tersebut perlahan berubah menjadi sebuah lingkaran yang kemudian berubah menjadi berbagai pola yang masing-masing merepresentasikan bahwa perusahaan SM Entertainment kedepannya dapat berkembang secara fleksibel mengikuti tren dan medium.

Dengan adanya pembaharuan Corporate Identity tersebut, SM Entertainment kini resmi tidak lagi hanya sebatas perusahaan produksi musik dan manajemen artis, namun juga memperluas bisnis kepada penjualan produk yang berhubungan dengan olahraga, fashion, dan gaya hidup. Sebelumnya, SM Entertainment juga telah membuka SUM cafe\&market, yaitu tempat berbelanja dan bersantai yang berada di lantai basement kantor SM Entertainment. SM Entertainment mendesain SUM sebagai gabungan dari cafe yang menjual beragam makanan dan kue-kue dengan desain ciri khas selebriti SM Entertainment, dan market/store dengan konsep sama, menjual berbagai snack seperti 'TVXQ Truffle \& Chocolate, atau 'Super Junior Ramen', dan berbagai oleh-oleh yang bisa dibawa pulang (Visit Seoul, 2016).

Selain SUM Cafe\&Market, SM Entertainment juga telah membangun gedung SMTOWN Coex Artium, yaitu sebuah pusat perbelanjaan yang berlokasi di Gangnam, Seoul. Gedung ini terdiri dari 6 lantai dengan pembagian lantai pertama adalah welcome stage, lantai kedua merupakan toko souvenir yang menjual pernak-pernik oleh-oleh ala SMTOWN, lantai ketiga museum berisikan pameran barang-barang dan sejarah para artis SM Entertainment, lantai keempat cafe yang juga dilengkapi dengan tempat penjualan souvenir, serta lantai kelima dan keenam yang berfungsi sebagai teater pertunjukan artis-artis SM Entertainment baik pertunjukan langsung maupun pertunjukan 3D. Semenjak dibuka, SMTOWN Coex Artium menjadi hot place tidak hanyabagi penggemar dari Korea Selatan, melainkan populer secara global. Korea 
Tourism Organization (KTO) bahkan sudah lebih dari sekali mencantumkan SMTOWN Coex Artium sebagai rekomendasi destinasi wisata. Pembukaan secara resmi SMTOWN Coex Artium diumumkan langsung oleh KTO pada situs webnya, begitu juga dengan rekomendasi tempat belanja perintilan hallyu, di mana KTO memasukkan SMTOWN Coex Artium sebagai salah satunya.

SM Entertainment dapat dikatakan telah berhasil menimbulkan brand awareness kepada publik baik di dalam maupun luar negeri. Alasan pertama karena brand-brand produk terkemuka di Korea Selatan sampai sekarang masih mempercayakan produk mereka untuk dipromosikan dengan artis-artis SM Entertainment sebagai brand ambassadornya. Kedua, tingginya ketertarikan publik di luar Korea Selatan kepada konten SM Entertainment sehingga juga menimbulkan ketertarikan untuk berkunjung ke pusat perbelanjaan serta membeli produk-produk fisik yang dikeluarkan baik secara langsung maupun online. Seiring dengan meledaknya Hallyu di berbagai negara, permintaan terhadap barang-barang yang berbau K-Pop dan KCulture tentunya semakin meningkat secara global. KTO menyebutkan bahwatren membeli dan mengumpulkam barang-barang yang ada kaitannya dengan selebriti hallyu sekarang sudah mencapai level yang lebih tinggi. Dalam pemasaran produk-produk di bawah brandnya, SM Entertainment membuka online shop global yang dapat dijangkau penggemar dengan mengakses link https://smglobalshop.com/. Link tersebut akan mengarahkan kepada laman web resmi online shop milik SM Entertainment untuk berbelanja yang memungkinkan shipping internasional. Keberadaan SM Global Shop membuktikan bahwa tren membeli produkproduk brand SM Entertainment juga sudah mencapai level global dan banyak diminati di seluruh dunia.

Berbekal New Culture Technology, SM Entertainment juga kerap menjalankan aktivitas seperti investasi asing. Mengikuti definisi dari Sornarajah, penanaman modal asing itu sendiri adalah kegiatan termasuk transfer modal baik berupa aset nyata maupun tidak nyata dari suatu negara ke negara lain, bertujuan untuk dipakai di negara tersebut, sehingga menghasilkan keuntungan di bawah kendali total ataupun sebagian dari pemilik modal tersebut (Sornarajah, 2017). Sebagai perusahaan yang memiliki strategi bisnis diversifikatif sebagaimana tercantum dalam kerangka kerja New Culture Technology, SM Entertainment menafirkan bisnis K-Pop tidak hanya sebatas bisnis pertunjukan saja, melainkan sudah mencakup bisnis berbagai produk kebudayaan Korea Selatan lainnya. Salah satu perwujudan dari strategi bisnis diversifikatif tersebut adalah memperluas cakupan bisnis dengan menanamkan modal atau berinvestasi di berbagai negara.

Salah satu contoh negara yang menjadi target penanaman modal oleh SM Entertainment adalah Indonesia. Pada tahun 2017, SM Entertainment menjadi salah satu perusahaan yang mengikuti 'Indonesia-Korea Business Summit 2017' yang diadakan di Shangri-La Hotel Jakarta. Sebagai perusahaan manajemen artis terbesar di Korea Selatan, SM Entertainment yang diwakili oleh Lee Sooman dan Leeteuk Super Junior menjadi perwakilan dari industri kreatif Korea Selatan. Menurut salah satu portal berita Indonesia, Kepala Badan Koordinasi Penanaman Modal (BKPM) Thomas Trikasih Lembong memang menyatakan bahwa Indonesia membidik Investasi dari Korea Selatan salah satunya pada industri kreatif (Lumanauw, 2017).

SM Entertainment kemudian menjadi salah satu perusahaan yang menanamkan modal di Indonesia khususnya pada sektor Industri Kreatif tersebut dan semakin memperluas bisnisnya di Indonesia. Hal ini dibuktikan dengan Kerja sama yang terjalin antara SM Entertainment dengan PT Transmedia Corpora satu tahun setelahnya, yang berupa Kerja sama di bidang talent management, produksi konten, digital, dan gaya hiburan. Kerja sama ini dilatarbelakangi oleh kesuksesan budaya KPop, Hallyu yang mendunia dan mampu 
menghasilkan devisa ekspor yang besar bagi Korea Selatan (Youtube CNN Indonesia, 2019). Dengan demikian, dijalinnya kerjasama oleh Transmedia dengan SM Entertainment tersebut membuktikan keunggulan SM Entertainment dalam konteks Hallyu sehingga dipercaya menjadi partner dalam berbagai bidang untuk pengembangan budaya seperti yang disebutkan di atas. Memang disebutkan bahwa Transmedia berharap melalui Kerja sama ini SM Entertainment sebagai pelopor dari Korean wave dan berpengalaman tingkat dunia dapat berbagi pengalaman dalam implementasi manajemen mereka mulai dari seleksi peran, pelatihan, produksi, marketing, dan talent management sehingga dapat digunakan untuk mengembangkan industri pop Indonesia (Budiartie, 2019). Keseluruhan dari yang disebutkan tersebut memang merupakan strategi inti milik SM Entertainment yang ada di dalam New Culture Technology. Mengikuti kerjasama dengan Transmedia, pada tahun berikutnya SM Entertainment membuka kantor cabang Indonesia yang bertempat di lantai lima mall FX Sudirman Jakarta. Meskipun hanya beroperasi sebagai kantor perwakilan dan bukan semacam pop-up store, kantor SM Entertainment Indonesia tetap dibanjiri oleh para penggemar yang ingin merasakan suasana tempat kerja asal idola yang mereka sukai.

SM Entertainment tidak hanya memilih Asia sebagai target pasar dan penanaman modal. Kerja sama SM Entertainment dengan Capitol Records merupakan salah satu contoh pelebaranbisnis SMEntertainment di Amerika. Capitol Records, anak perusahaan dari Universal Music Group, adalah sebuah label rekaman besar di Amerika Serikat yang menaungi artis-artis ternama seperti Calum Scott, Halsey, Katy Perry, Sam Smith, dan banyak artis lainnya. Kerja sama SM Entertainment dengan Capitol Records ditandai dengan bergabungnya boygroup dari SM Entertainment, NCT 127, ke dalam jajaran artis yang ditangani Capitol Music Group pada tanggal 4 April 2019 (E. Cha, 2019). Berdasarkan perjanjian Kerja sama tersebut, Capitol Music Group dan label layanan distribusi independen Caroline akan menangani proses distribusi dan marketing NCT 127 untuk kawasan Amerika Serikat yang sering disebut "the most global territory".

Selain menangani NCT 127 di bawah label mereka, pada Agustus 2019, Capitol Records bersama dengan SM Entertainment juga meluncurkan proyek baru yaitu mendebutkan boygroup yang diberi nama SuperM (SM Entertainment, 2019). Proyek SuperM dikerjakan dengan campur tangan langsung dari Lee Sooman dan menyasar pasar global dimulai dari debut resminya di Amerika Serikat. Pada wawancara singkat dalam program "SuperM The Beginning" yang disiarkan di stasiun televisi SBS Korea, Ketua sekaligus CEO dari Capitol Music Group, Steve Barnett menyatakan bahwa di samping kesuksesan Capitol dalam mengorbitkan berbagai bintang terkenal, ada semacam "missing link" yang ingin ia lengkapi yaitu bekerja sama dengan orang-orang di industri K-Pop yang sangat populer saat ini. Oleh sebab itu Barnett meminta Michelle Jubilee sebagai Chief Operation Officer (COO) Capitol Music Group untuk mencari orang-orang terbaik dalam industri tersebut untuk diajak menjadi partner dalam berbisnis, yang pada akhirnya pilihan jatuh kepada SM Entertainment. Kerja sama antara kedua perusahaan besar ini memberikan hasil yang luar biasa dengan kesuksesan SuperM yang langsung memuncaki Billboard Chart dengan album debut mereka yang berjudul 'SuperM' (Caufield, 2019). Keinginan Capitol Music Group untuk menjalin Kerja sama dan pencapaian tersebut sekali lagi menjadi pembuktian kekuatan SM Entertainment sebagai perusahaan yang diakui memimpin dalam hal hallyu.

Kedua contoh di atas merupakan perwujudan investasi asing yang dilakukan SM Entertainment. Melalui berbagai Kerja sama dengan perusahaan lain di berbagai negara, SM Entertainment menanamkan modalnya dengan melakukan transfer aset baik berupa aset nyata maupun tidak nyata ke berbagai belahan dunia. Kerja sama SM Entertainment dengan Transmedia misalnya, merupakan contoh 
transfer aset tidak nyata, di mana SM Entertainment melalui kantor perwakilannya di Indonesia berbagi teknik-teknik implementasi New Culture Technology untuk melahirkan konten kreatif baru bersama pihak Indonesia. Di sisi lain kerjasama dengan Capitol Records merupakan contoh manajemen transfer aset nyata berupa proyek kedua label untuk mendebutkan grup-grup seperti NCT 127 dan SuperM dan mempromosikannya di pasar Amerika.

Selain di Indonesia dan Amerika Serikat, SM Entertainment memiliki cakupan investasi yang luas dibuktikan dengan Kerja sama yang dilakukan dengan berbagai perusahan lainnya di berbagai negara seperti Avex Japan dan Universal Music Taiwan, Malaysia, Singapura dan Indonesia, PolyEast Records Filiphina, GMM International di Thailand, Warner Music, dan beberapa label lainnya. Terlepas dari penerimaan yang baik dari publik negaranegara yang menerima investasi, SM Entertainment selaku penanam modal asing harus selalu mengikuti dan menghormati nilai serta tradisi yang dimiliki negara tujuan investasi dan berhati-hati agar aktivitas bisnis di luar negeri tidak menciptakan citra buruk bagi Korea Selatan.

Terakhir, perusahaan SM Entertainment mengimplementasikan New Culture Technology miliknya ke dalam kegiatan Corporate Social Responsibility (CSR). SM SMile merupakan rangkaian berbagai program CSR yang dilakukan oleh SM Entertainment berkorelasi dengan SDGs poin keempat, yaitu memastikan pendidikan yang inklusif dan berkualitas. Dengan visi membantu anak-anak dan remaja mengembangkan mimpi dan harapan mereka melalui pendidikan musik, SM Entertainment telah mengimplementasikan berbagai aktivitas kontribusi sosial di Korea dan kawasan Asia (SM Entertainment, n.d.-b) seperti :

1. Social Service Group : Melakukan aktivitas volunteer bulanan secara regular dengan partisipasi sukarela dari para staf dan artis SMEntertainment.
2. Education and Culture : Memberikan dukungan kepada anak-anak remaja yang ingin menjadi musisi dengan menggunakan tenaga ahli dan infrastruktur yang dimiliki SM Entertainment.

3. Partnership : Mengimplementasikan berbagai aktivitas kontribusi sosial melalui Kerja sama dengan berbagai perusahaan dan organisasi-organisasi non-profit seperti UNICEF, Happiness Alliance, dan Korean Red Cross.

4. Donation and Sponsoring : Menyalurkan donasi dan mensponsori bagi yang membutuhkan bantuan.

CSR SM Smile diwujudkan dalam beberapa contoh program, pertama yaitu SMile Music Festival. SMile Music Festival adalah contoh program CSR yang dilakukan SM Entertainment dalam hal pendidikan dan kebudayaan. Program ini dimaksudkan untuk membantu anak-anak remaja yang memiliki mimpi untuk menjalani karir sebagai musisi. Dalam program SMile Music Festival, sekitar 10 tim dipilih dalam kategori band, paduan suara, dan grup dance, untuk kemudian dilath dan dimentori oleh para artis SMEntertainment beserta pelatih-pelatih profesional. Anak-anak hasil mentoring dan pelatihan tersebut kemudian akan ditampilkan dalam sebuah konser kolaborasi. Sejauh ini konser SMile Music festival sudah dilaksanakan sebanyak lima kali dalam kurun waktu 2015-2019 yang bertempat di SMTOWN Theatre, lantai 5 SMTOWN Coex Artium.

Program CSR SM Entertainment selanjutnya adalah SMile for U. Kegiatan ini berupa kampanye yang dilakukan untuk memberikan dukungan kepada anak-anak dan remaja di kawasan Asia untuk mendapatkan pendidikan musik. Kampanye ini dimulai semenjak SM Entertainment menandatangani MoU untuk Corporate Social Responsibility dengan Komite Korea Untuk UNICEF pada bulan November 2015, menargetkan beberapa daerah di Vietnam seperti Hanoi, Da Nang, Kon Tum, Gia Lai, dan Dien Bien. Dukungan yang 
diberikan oleh SM Entertainment mencakup pelatihan instruktur, pengembangan kurikulum pendidikan, dan dukungan berupa peralatan. Periode program ini adalah 6 tahun yaitu dimulai pada tahun 2016 sampai tahun 2022. Pada bulan November 2018, Siwon Super Junior yang sekarang merupakan Duta Besar Regional untuk UNICEF bersama dengan Jaemin NCT Dream melakukan kunjungan ke Vietnam dalam perayaan Hari Anak Sedunia (UNICEF, 2018). Tidak hanya menghadiri forum mengenai anti-bullying dan anti kekerasan terhadap anak, Siwon dan Jaemin juga mewakili CSR SM Entertainment dengan berkunjung ke sekolah yang menjadi proyek SM Entertainment dan UNICEF di Vietnam untuk menyaksikan bagaimana pelajaran musik diberikan kepada anak-anak Vietnam.

Selain kedua contoh di atas, SM Entertainment juga banyak melakukan berbagai kegiatan CSR lainnya secara rutin yang dapat dilihat di situs web resmi SM Entertainment. Dengan melakukan CSR, SM Entertainment secara tidak langsung mendapatkan image baik bagi perusahaan mereka. CSR yang dilakukan SM Entertainment memenuhi kriteria philantropic responsibility yaitu ekspektasi terhadap suatu perusahaan untuk menjadi corporate citizen yang baik dengan sukarela memberikan kontribusi secara finansial dan sumber daya manusia kepada masyarakat demi meningkatkan kualitas hidup masyarakat tersebut. Melalui SMile Music Festival dan SMile for U, SM Entertainment dilihat sebagai perusahaan yang memberikan harapan kepada anak-anak, tidak hanya di dalam namun juga di luar negeri, untuk mewujudkan impian mereka. Hal ini tentunya juga menjadi kontribusi besar yang diberikan SM Entertainment kepada citra Korea Selatan sebagai perusahaan yang berasal dari negara tersebut.

\section{KESIMPULAN}

Diplomasi publik sebagai soft power seringkali digunakanolehnegara dalamupaya pencapaian kepentingan. Seiring perkembangan jaman, aktor-aktor yang memiliki kapabilitas dalam pelaksanaan diplomasi publik juga semakin berkembang. Dengan mengambil SM Entertainment sebagai objek yang diteliti, penelitian kali ini mendapatkan temuan yang menegaskan bahwa sebuah perusahaan swasta saat ini juga dapat berperan dan berkontribusi dalam diplomasi publik sebuah negara dalam hubungan internasional. Dengan menggunakan strategi New Culture Technology, SM Entertainment melakukan berbagai aktivitas perusahaan yang kemudian setelah dijabarkan dengan memberikan contoh implementasi NCT tersebut ternyata memenuhi lima kategori kegiatan perusahaan yang terhitung sebagai kontribusi dalam diplomasi publik sesuai konsep corporate diplomacy milik Candace $\mathrm{L}$. White. Lima kategori tersebut adalah diplomasi kebudayaan, investasi asing, branding place/nation/destination, branding produk, dan corporate social responsibility (CSR).

Terpenuhinya kelima kategori kontribusi perusahaan pada diplomasi publik negara sesuai konsep dari Candace L. White oleh aktivitas SM Entertainment menggunakan NCT dan eksistensi SM Entertainment sebagai perusahaan yang masih terdepan dalam hallyu saatini membuktikan bahwa SMEntertainment melalui New Culture Technology sebagai strategi perusahaannya memang dapat dikatakan berperan besar dalam diplomasi publik Korea Selatan.

\section{DAFTAR PUSTAKA}

An0ya. (2016, February 17). Red Velvet Chosen as New Models for Cosmetics Brand the Saem | Soompi. https://www.soompi.com/article/822445wp $\mathrm{p} /$ red-velvet-chosen-as-new-models-forcosmetics-brand-the-saem

Armenia, R. (2018, March 26). Red Velvet Bakal Nyanyikan Dua Lagu Hit di Korea Utara.

https://www.cnnindonesia.com/hiburan/201 80326150908-227-285971/red-velvetbakal-nyanyikan-dua-lagu-hit-di-koreautara

Budiartie, G. (2019, February 21). Trans Media dan SM Entertainment Kawinkan Artis RI dan Kpop. https://www.cnbcindonesia.com/lifestyle/2 0190221101912-33-56793/trans-media- 
dan-sm-entertainment-kawinkan-artis-ridan-kpop

Caufield, K. (2019, October 13). SuperM's "The 1st Mini Album" Debuts at No. 1 on Billboard 200 Albums Chart | Billboard| Billboard.

https://www.billboard.com/articles/business /chart-beat/8532879/superm-the-1 st-minialbum-billboard-200-no-1

Chen, S. (2016). Cultural Technology: A Framework for Marketing Cultural Exports - Analysis of Hallyu (the Korean Wave). International Marketing Review, 33, 25-50. https://doi.org/10.1108/IMR-07-2014-0219

Cull, N. J. (2008). Public diplomacy: Taxonomies and histories. Annals of the American Academy of Political and Social Science, 616(1), 31-54. https://doi.org/10.1177/0002716207311952

E. Cha. (2019, April 5). NCT 127 Signs Distribution Deal With U.S. Label Capitol Music Group | Soompi. https://www.soompi.com/article/1315218w $\mathrm{pp} /$ nct-127-signs-distribution-deal-with-us-label-capitol-music-group

Hazliansyah. (2012, March 20). Super Junior Gelar Super Show 4 di Jakarta April Mendatang | Republika Online. https://www.republika.co.id/berita/senggan $\mathrm{g} / \mathrm{musik} / 12 / 03 / 20 / \mathrm{m} 16 \mathrm{w} 4 \mathrm{~s}-$ super-juniorgelar-super-show-4-di-jakarta-aprilmendatang

Hennida, C., Felayati, R. A., Wijayanti, S. H., \& Perdana, A. R. (2017). Budaya dan Pembangunan Ekonomi di Jepang, Korea Selatan dan China. Jurnal Global \& Strategis, $\quad 10(2), \quad 248$. https://doi.org/10.20473/jgs.10.2.2016.248263

Hilda. (2018, July 14). Peran Pemerintah Korea terhadap K-Pop - ERA.ID. https://era.id/lounge/5398/peranpemerintah-korea-terhadap-k-pop

Huat, C. B., \& Iwabuchi, K. (2008). East asian pop culture: Analysing the Korean Wave.

Jung, S., \& Shim, D. (2014). Social distribution: K-pop fan practices in Indonesia and the "Gangnam Style" phenomenon. International Journal of Cultural Studies, 17(5), 485-501. https://doi.org/10.1177/1367877913505173

Kedutaan Besar Republik Korea untuk Republik Indonesia. (n.d.). Hallyu: Gelombang Korea (한류:Korea
Wave)Kedutaan Besar Republik Korea untuk Republik Indonesia. Retrieved January 13, 2021, from http://overseas.mofa.go.kr/id$\mathrm{id} /$ wpge/m_2741/contents.do

Lee, Geun. (2009). A Soft Power Approach to the "Korean Wave." The Review of Korean Studies, 12(2), 123-137. https://doi.org/10.25024/review.2009.12.2. 006

Lee, M. H. (2014). Penetration Strategies of SM Entertainment in Global Market. Journal of the Korea Society of IT Services, 13(3), 7792.

https://doi.org/10.9716/kits.2014.13.3.077

Lumanauw, N. (2017, March 14). "IndonesiaKorea Business Summit", Jokowi Sampaikan Pidato Kunci. https://www.beritasatu.com/ekonomi/41923 4/indonesiakorea-business-summit-jokowisampaikan-pidato-kunci

McDonald, J. W. (2012). The Institute for Multi-Track Diplomacy. Journal of Conflictology, 3(2). https://doi.org/10.7238/joc.v3i2.1629

Melissen, J. (ed). (2006). The New public diplomacy: soft power in international relations. In Choice Reviews Online (Vol. 44, Issue 03). Palgrave Macmillan. https://doi.org/10.5860/choice.44-1781

Nye, J. S. (2008). Public diplomacy and soft power. Annals of the American Academy of Political and Social Science, 616(1). https://doi.org/10.1177/0002716207311699

Ordeix-Rigo, E., \& Duarte, J. (2009). From Public Diplomacy to Corporate Diplomacy: Increasing Corporation's Legitimacy and Influence. American Behavioral Scientist, 53(4), 549-564. https://doi.org/10.1177/0002764209347630

Putri, I. P., Liany, F. D. P., \& Nuraeni, R. (2019). K-Drama dan Penyebaran Korean Wave di Indonesia. ProTVF, 3(1), 68. https://doi.org/10.24198/ptvf.v3i1.20940

Ramirez, R. (2013, March 20). Performances from Music Bank in Jakarta, Indonesia| Soompi.

https://www.soompi.com/article/483037wp p/music-bank-in-jakarta

Shim, D. (2006). Hybridity and the rise of Korean popular culture in Asia. Media, Culture and Society, 28(1), 25-44. https://doi.org/10.1177/0163443706059278 SM Entertainment.(n.d.-a). Retrieved January 
12 ,

2021 ,

from

https://www.smentertainment.com/Overvie w/Introduction

SM Entertainment. (n.d.-b). SMile Overview. Retrieved January 13, 2021, from https://www.smentertainment.com/Overvie w/Responsibility

SM Entertainment. (2017, November 1). SM Entertainment releases new CI! https://www.smentertainment.com/PressCe nter/Details/818

SM Entertainment. (2019, August 8). SM \& U.S. Capitol Music Group to launch the new global project 'SuperM.' https://www.smentertainment.com/PressCe nter?Page $=13 \&$ SearchString $=$ SuperM

SMTOWN. (2016, February 1). SMTOWN: New Culture Technology, 2016 - YouTube. https://www.youtube.com/watch?v=Ky5Nv WsXnn8

Sornarajah, M. (2017). The International Law on Foreign Investment (4th ed.). Cambridge University Press. https://doi.org/DOI: $10.1017 / 9781316459959$

The Economist. (2010, January 25). South Korea's pop-cultural exports - Hallyu, yeah! | Asia | The Economist. https://www.economist.com/asia/2010/01/2 5/hallyu-yeah

Trisni, S.-. (2019). South Korean Government's Role in Public Diplomacy: A Case Study of the Korean Wave Boom. Andalas Journal of International Studies (AJIS), 8(1), 31. https://doi.org/10.25077/ajis.8.1.3142.2019

U.S. Department of State. (2005, September). 2005 - Cultural Diplomacy: The Linchpin of Public Diplomacy. https://20092017.state.gov/pdcommission/reports/5425 6.htm

UNICEF. (2018, November 15). Siwon Choi and Jaemin Na join a cast of stars to celebrate World Children's Day across the world.

https://www.unicef.org/vietnam/pressreleases/siwon-choi-and-jaemin-na-joincast-stars-celebrate-world-childrens-dayacross-world

Visit Seoul. (2016, December 26). SM TOWN\&STORE.

https://english.visitseoul.net/attractions/SU M-Market-EN_/20302

W Production. (2012, August 2). Press Release. https://web.facebook.com/22546167417236 0/photos/a.226889867362874/4253521641 83309/?type $=3 \&$ theater\&_rdc $=1 \& \_r d r$

White, C. L. (2015). Exploring the role of private-sector corporations in public diplomacy. Public Relations Inquiry, 4(3), 305-321. https://doi.org/10.1177/2046147X1561488 3

Youtube CNN Indonesia. (2019, February 2). Kerjasama Transmedia-SM Entertainment YouTube.

https://www.youtube.com/watch?v=YTNg 9M4dW44

\section{BIOGRAFI}

Maharani Putri merupakan mahasiswi Program Studi Ilmu Hubungan Internasional, Fakultas Ilmu Sosial dan Ilmu Politik, Universitas Andalas. Memiliki ketertarikan dalam mengkaji diplomasi baik diplomasi publik dan jenis-jenis diplomasi lainnya dalam hubungan interna sional.

Sofia Trisni, S.IP, MA (IntRel) merupakan pengajar pada Program Studi Ilmu Hubungan Interna sional, Fakultas Ilmu Sosial dan Ilmu Politik, Universitas Andalas. Memiliki ketertarikan dalam mengkaji diplomasi, diplomasi publik, dan kebijakan luar negeri Indonesia. 